\title{
Peripheral vascular dysfunction in migraine: a review
}

\author{
Simona Sacco ${ }^{1 *}$, Patrizia Ripa ${ }^{1}$, Davide Grassi ${ }^{2}$, Francesca Pistoia ${ }^{1}$, Raffaele Ornello ${ }^{1}$, Antonio Carolei ${ }^{1}$ \\ and Tobias Kurth ${ }^{3,4}$
}

\begin{abstract}
Numerous studies have indicated an increased risk of vascular disease among migraineurs. Alterations in endothelial and arterial function, which predispose to atherosclerosis and cardiovascular diseases, have been suggested as an important link between migraine and vascular disease. However, the available evidence is inconsistent. We aimed to review and summarize the published evidence about the peripheral vascular dysfunction of migraineurs.

We systematically searched in BIOSIS, the Cochrane database, Embase, Google scholar, ISI Web of Science, and Medline to identify articles, published up to April 2013, evaluating the endothelial and arterial function of migraineurs.

Several lines of evidence for vascular dysfunction were reported in migraineurs. Findings regarding endothelial function are particularly controversial since studies variously indicated the presence of endothelial dysfunction in migraineurs, the absence of any difference in endothelial function between migraineurs and non-migraineurs, and even an enhanced endothelial function in migraineurs. Reports on arterial function are more consistent and suggest that functional properties of large arteries are altered in migraineurs.

Peripheral vascular function, particularly arterial function, is a promising non-invasive indicator of the vascular health of subjects with migraine. However, further targeted research is needed to understand whether altered arterial function explains the increased risk of vascular disease among patients with migraine.
\end{abstract}

Keywords: Migraine; Migraine with aura; Arterial stiffness; Endothelial function; Flow mediated dilation; Pulse wave velocity; Augmentation index; Stroke; Coronary artery disease; Cardiovascular disease; Risk factors

\section{Introduction}

Numerous studies have indicated that migraineurs have an increased risk of vascular diseases. The association between migraine and ischemic stroke was the earliest to be recognized [1-3]. Thereafter, migraine has been associated also with myocardial infarction, hemorrhagic stroke, retinal vasculopathy, cardiovascular mortality, incidental brain lesions, including infarct-like lesions, and in some instances also with peripheral artery disease (Table 1) [4-7]. Mechanisms which may explain these

\footnotetext{
* Correspondence: simona.sacco@yahoo.com

${ }^{1}$ Department of Neurology and Regional Headache Center, University of

L'Aquila, Piazzale Salvatore Tommasi 1, L'Aquila 67100, Italy

Full list of author information is available at the end of the article
}

associations have been discussed previously [5,8-10]. One of the plausible mechanisms predisposing individuals to atherosclerosis and vascular diseases is endothelial and arterial dysfunction [11]. Consequently, several studies have evaluated the vascular function of migraineurs outside the brain, providing equivocal results. The aim of the present study was to review the published evidence linking peripheral arterial function with migraine.

\section{Background information about arterial and endothelial function and its measurements}

The endothelium, i.e. the inner layer of cells of blood vessels, has physiologically favorable and atheroprotective

\section{它}


Table 1 Evidence referring to the association between migraine and the risk of vascular disease

Ischemic stroke

Numerous studies demonstrating an association with any migraine [e1-e22];

Definite association with migraine with aura [e1,e3-e4,e7-e8,e11-e12,e15-e16,e19-e21];

No definite association with migraine without aura [e1,e3,e7,e11-e12,e16,e19-e20];

Association with migraine with aura confirmed by three meta-analyses [e23-e25].

Transient ischemic attack

The risk seems to be increased in migraineurs, although this issue has not been extensively investigated due to a challenging overlap of symptoms with migraine aura [e6,e19].

Hemorrhagic stroke

Several studies addressing the topic and providing inconsistent results [e5,e8-e10,e26-e29];

A meta-analysis of those studies indicating a small but significant association [e30];

No definite conclusion regarding migraine type.

Cardiac events

Two large studies indicating an association with any migraine in men and women and with migraine with aura in women (data not available for men) [e1,e2]; Conflicting results provided by other available studies [e4,e31-e33];

No association with any migraine in meta-analysis of data but few studies available [e23]; No analysis according to migraine type due to lack of data.

A recent study reporting an association between migraine (any migraine, migraine with aura and migraine without aura) and myocardial infarction [e4].

Vascular death

A meta-analysis and a large study supporting an association with migraine with aura [e23];

No association with any migraine according to meta-analysis of data [e23].

Other vascular diseases

Studies indicating a possible association with any migraine and retinal disease [e34,e35] and peripheral artery disease [e36-e37].

Brain lesions

Migraine has been associated with white-matter hyperintensities and infarct-like lesions [e38-e42];

Association of migraine with white matter hyperintensities confirmed in two meta-analyses [e41,e43]; no definite association with infarct-like lesions [e43]

References are listed in Additional file 1.

effects [12]. It works as both a receptor and effector organ and responds to each physical or chemical stimulus with the release of substances, including nitric oxide (NO), with which the endothelium maintains vasomotor balance and vascular-tissue homeostasis [13]. The established cardiovascular risk factors cause oxidative stress initiating a chronic inflammatory process which alters the endothelial cells capacity. This leads to "endothelial dysfunction" with a reduction in endothelium-dependent vasodilation and the induction of a specific state of "endothelial activation," characterized by a proinflammatory, proliferative, and procoagulatory milieu which favors all stages of atherogenesis, pathological inflammatory processes, and vascular disease [14]. Endothelial dysfunction represents an early step in the development of atherosclerosis [15]. Endothelial function can be investigated by invasive and non-invasive tests [16]. Invasive tests are based upon intra-arterial infusion of vasoactive agents. Among the several non-invasive methods of measuring endothelial function, flow-mediated dilation (FMD), laser Doppler flowmetry, and digital pulse amplitude tonometry (PAT) are the most widely adopted [16-18]. Figure 1 shows details about measurement of FMD [16-19].

Measures of arterial elasticity are also being investigated as non-invasive means of gauging vascular health [14]; the most commonly considered parameters are pulse wave velocity (PWV), augmentation index (AIx) and local arterial distensibility in the carotid artery or in the aorta. While FMD addresses functional status of the endothelium, PWV, AI, and local arterial distensibility are better related to structural changes in the vessel wall. PWV is an indicator of segmental arterial stiffness. Carotid-femoral PWV is the gold standard of assessment (Figure 2), but it is difficult to measure, so in clinical practice it can be replaced by the measurement of brachial-ankle PWV (although this measurement includes some muscular arteries and not only the elastic ones). The AIx (Figure 3) is an index related to the stiffness of the systemic arterial tree. An increase in arterial stiffness leads to a more proximal point of reflection, thus altering the wave profile as measured by the instruments. Local arterial distensibility is assessed by measuring the minimum and maximum diameter of central arteries - such as the carotid artery or aorta by ultrasound or MRI with simultaneous recording of the blood pressure in the arterial district from which the diameters are obtained.

\section{Search strategy and selection criteria}

Data for this review were obtained through searches in BIOSIS, the Cochrane database, Embase, Google scholar, ISI Web of Science, and Medline from their first availability up to April 2013. The search terms included "migraine" OR "headache" AND ("endothelial function", "endothelial injury", "arterial stiffness", "arterial distensibility", "vascular resistance", "vascular reactivity", "flow-mediated dilation", "forearm blood flow", "arterial pulse wave velocity", "augmentation index"). We also searched reference lists of identified articles and papers quoting identified articles. We reviewed only studies published in English. 

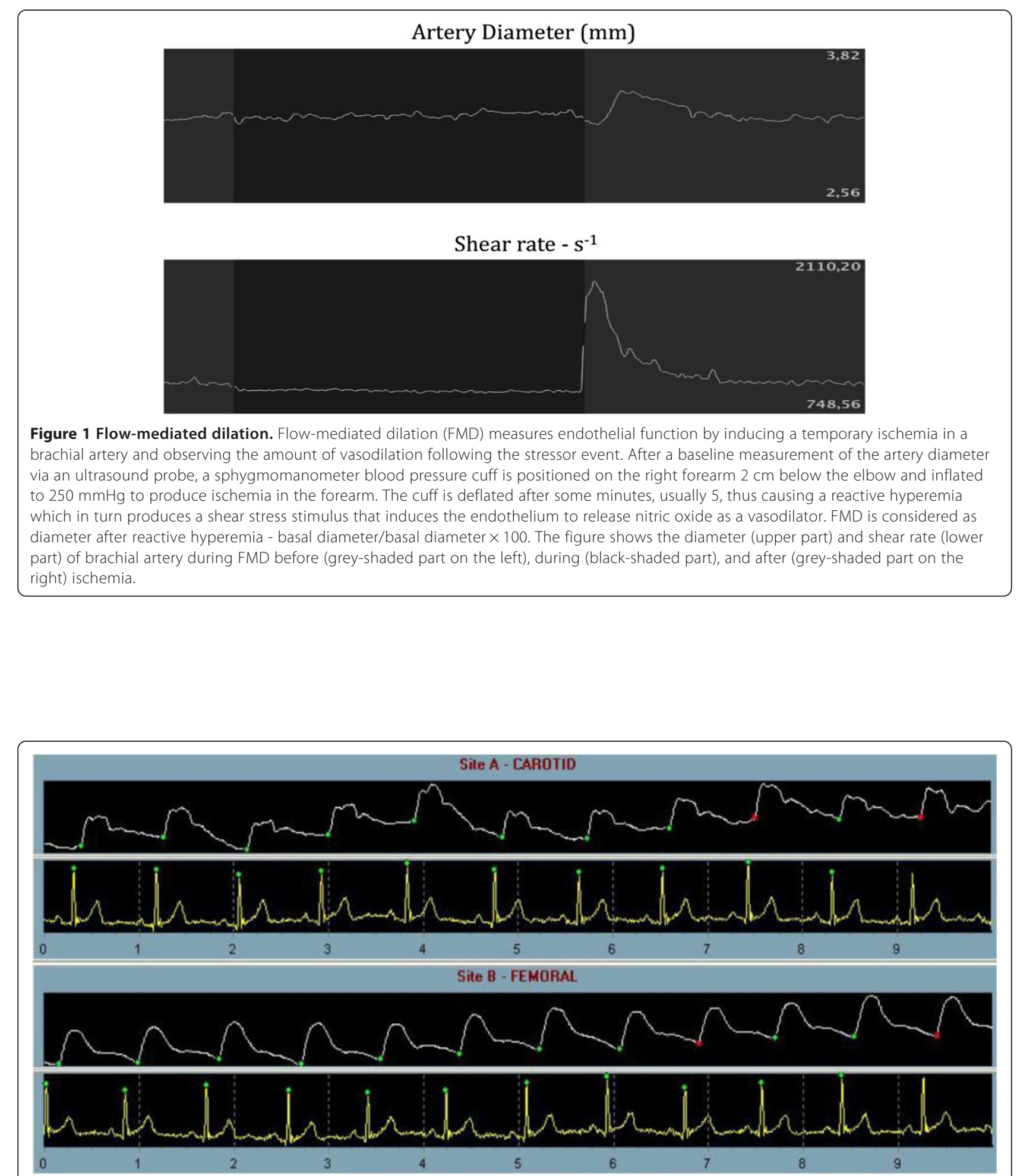

Figure 2 Carotid-Femoral Pulse Wave Velocity. Increased arterial stiffness leads to increased velocity of the pulse wave generated in the arteries by the contraction of the left ventricle. Pulse wave velocity (PW) consists in measuring pulse wave profiles by tonometry at two distant locations (carotid and femoral) and measuring the delay in the onset of the wave between those two locations. PWV is calculated as the distance traveled by the wave divided by the time taken to travel that distance. Surface distance between the two recording sites and simultaneously recorded electrocardiograms are used to calculate wave transit time. The figure shows tonometric (white lines) recordings of the carotid (above) and femoral (below) artery waves according with simultaneous electrocardiographic (yellow lines) ' $R$ ' wave of the electrocardiogram as a timing reference. 


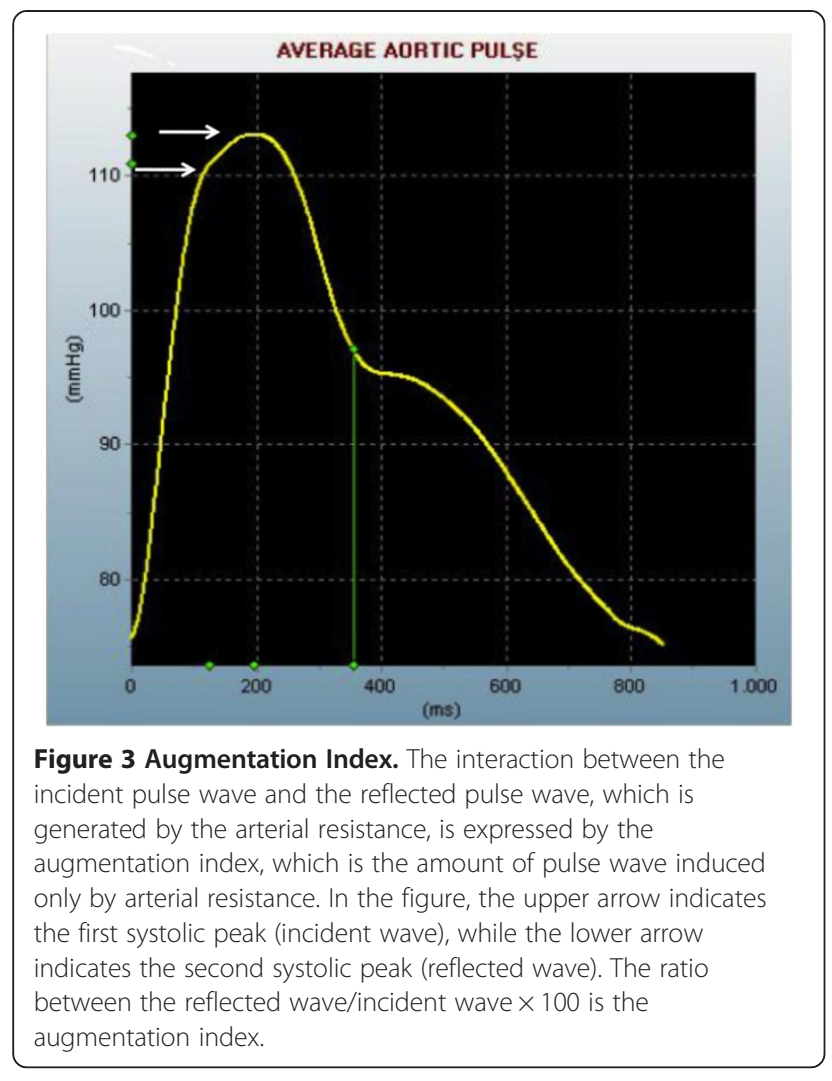

\section{Review}

Arterial and endothelial function in migraineurs

Several lines of evidence for vascular dysfunction have been identified in migraineurs and there is increasing evidence to suggest that in migraineurs the vascular system is impaired not only within the brain.

\section{Endothelial function in migraineurs}

The many studies assessing endothelial function in migraineurs have used heterogeneous techniques and indicators as shown in Tables 2, 3 and 4. Most of them assessed endothelial function by measuring FMD (Table 2) [20-30], some used PAT (Table 3) [31,32], some measured peripheral vasodilation in response to pharmacological stimuli (Table 3) [20,30,33-35], and others assessed endothelial progenitor cells (EPCs) (Table 4) [23,36,37]. Findings were not consistent across the studies. Several among the available studies did not reveal any alteration in the endothelial function of migraineurs. Six of them did not find any difference in FMD between migraineurs and control subjects (Table 2) [20-23,25,26] and a further study confirmed the lack of any alteration in endothelial function assessed by PAT ratio (Table 3) [32]. Three studies assessing peripheral vasodilation after pharmacological stimuli found comparable responses in subjects with and without migraine (Table 3) [20,33,35]. However, other studies supported the presence of endothelial dysfunction in migraineurs. Four studies reported decreased FMD in migraineurs [24,27,29,30]; in one of those studies, FMD correlated with dysfunction of the autonomic nervous system (Table 2) [24]. Another study, using PAT, reported that subjects with chronic migraine had worse endothelial function (Table 3) [31]. A further study found an abnormal vascular response to dilating pharmacological stimuli (Table 3) [34]. The possible underlying mechanisms of endothelial dysfunction in those studies were unclear. Since the impairment of FMD was demonstrated also in individuals with recent onset of migraine it is unlikely that the disturbance was a consequence of longstanding and repeated exposure to the vasoconstrictor agents used for migraine treatment [27]. In addition, the results of one study suggested that the impaired vascular reactivity in migraineurs is entirely attributable to a reduced response of vascular smooth muscle cells to NO while the endothelial response to NO appeared intact [34]. Some additional studies supported the presence of an endothelial dysfunction in migraineurs by documenting a decreased number of EPCs [23,36] or a higher number of more mature EPCs (which could be associated with potential endothelial damage) in migraineurs (Table 4) [37]. EPCs maintain the integrity of damaged endothelium and are considered a marker of endothelial function [38]. At variance with other studies, Vernieri et al., found that subjects with migraine with aura had higher FMD than both control subjects and migraine without aura subjects indicating an excessive arterial response to hyperemia. It is suggested that this is probably an effect of an increased sensitivity to endothelium-derived $\mathrm{NO}$ or of increased release of NO induced by shear stress (Table 2) [28]. In agreement, Yetkin et al., found that migraineurs have an increased nitrate-mediated response showing a major role of NO supersensitivity in migraine pathophysiology (Table 3) [30].

Several studies support the presence of biochemical changes in the endothelial activation of migraineurs. These biochemical changes may precede structural damage. In particular, alterations in the NO pathway have been described $[30,39,40]$ as well as increased levels of calcitonin gene-related peptide (CGRP), vascular endothelial growth factors (VEGF), von Willebrand factor (vWF) activity, tissue plasminogen activator antigen, C-reactive protein and endothelin-1 $[21,23,40]$. Recently, a study involving 40 non-hypertensive subjects with migraine without aura randomized to treatment with enalapril $5 \mathrm{mg}$ twice a day for 3 months or to placebo, showed that active treatment was associated with an increase in FMD values [41]. 
Table 2 Studies on endothelial function using flow-mediated dilation in migraineurs

\begin{tabular}{|c|c|c|c|c|c|c|}
\hline $\begin{array}{l}\text { Study (First } \\
\text { author, year) }\end{array}$ & $\begin{array}{l}\text { Study } \\
\text { design }\end{array}$ & $\begin{array}{c}\text { Patients } \\
\text { included (n) }\end{array}$ & $\begin{array}{c}\% \\
\text { women }\end{array}$ & $\begin{array}{l}\text { Exclusion } \\
\text { criteria }\end{array}$ & $\begin{array}{l}\text { Migraine } \\
\text { diagnosis }\end{array}$ & Results \\
\hline \multirow[t]{2}{*}{ De Hoon, 2006 [20] } & \multirow[t]{2}{*}{$\mathrm{CC}$} & Migraine: 10 & \multirow[t]{2}{*}{60} & \multirow[t]{2}{*}{ CVD, HYP, DM, dyslipidemia, CS } & \multirow[t]{2}{*}{ ICHD-I } & \multirow{2}{*}{$\begin{array}{l}\text { No differences in FMD } \\
\text { between migraineurs } \\
\text { and controls }\end{array}$} \\
\hline & & Controls: 10 & & & & \\
\hline \multirow[t]{4}{*}{ Hamed, 2010 [21] } & \multirow[t]{4}{*}{$\mathrm{CC}$} & Migraine: 38 & \multirow[t]{4}{*}{89} & \multirow{4}{*}{$\begin{array}{l}\text { CVD and vascular RF, DM, CS, } \\
\text { alcoholism, active gastrointestinal } \\
\text { disease, gout, epilepsy, recent } \\
\text { infection, renal failure, pregnancy } \\
\text { or lactation, regular use FANS or } \\
\text { antimigrainous drugs and OC }\end{array}$} & \multirow[t]{4}{*}{ ICHD-II } & \multirow{4}{*}{$\begin{array}{l}\text { No differences in FMD } \\
\text { between migraineurs } \\
\text { and controls }\end{array}$} \\
\hline & & (MwA: 14; & & & & \\
\hline & & MwoA: 24) & & & & \\
\hline & & Controls: 35 & & & & \\
\hline \multirow[t]{3}{*}{ Perko, 2011 [22] } & \multirow[t]{3}{*}{ CC } & MwA: 20 & \multirow[t]{3}{*}{80} & \multirow{3}{*}{$\begin{array}{l}\text { CVD, obesity, HYP, dyslipidemia, } \\
\text { pregnancy or lactation and regular } \\
\text { use of vasoactive drugs }\end{array}$} & \multirow[t]{3}{*}{ ICHD-II } & \multirow{3}{*}{$\begin{array}{l}\text { No differences in FMD } \\
\text { between migraineurs } \\
\text { and controls }\end{array}$} \\
\hline & & MwoA: 20 & & & & \\
\hline & & Controls: 20 & & & & \\
\hline \multirow[t]{4}{*}{ Rodriguez-Osorio, 2012 [23] } & \multirow[t]{4}{*}{$\mathrm{CC}$} & Migraine : 47 & \multirow[t]{4}{*}{98} & \multirow{4}{*}{$\begin{array}{l}\text { CAD, inflammatory disease, obesity, } \\
\text { HYP, DM, dyslipidemia, CS, infectious } \\
\text { disease, severe systemic disease, } \\
\text { ovarium pathology, pregnancy or } \\
\text { lactation, use of vasoactive drugs }\end{array}$} & \multirow[t]{4}{*}{ ICHD-\|I } & \multirow{4}{*}{$\begin{array}{l}\text { No differences in FMD } \\
\text { between migraineurs } \\
\text { and controls }\end{array}$} \\
\hline & & (MwA:14; & & & & \\
\hline & & MwoA: 33) & & & & \\
\hline & & Controls: 23 & & & & \\
\hline \multirow[t]{2}{*}{ Rossato, 2011 [24] } & \multirow[t]{2}{*}{$\mathrm{CC}$} & Migraine: 20 & \multirow[t]{2}{*}{75} & \multirow{2}{*}{$\begin{array}{l}\text { Age } \geq 50 \text {, vascular } R F, C S \text {, use of } \\
\text { vasoactive drugs }\end{array}$} & \multirow[t]{2}{*}{ Not reported } & \multirow{2}{*}{$\begin{array}{l}\text { Decreased FMD in } \\
\text { migraineurs }\end{array}$} \\
\hline & & Controls: 20 & & & & \\
\hline \multirow[t]{2}{*}{ Silva, 2007 [25] } & $\mathrm{CC}$ & $\begin{array}{c}\text { Migraine: } 50 \\
\text { (MwA: 25; MwoA: 25) }\end{array}$ & 88 & None & $\mid C H D-\|$ & $\begin{array}{l}\text { No differences in FMD } \\
\text { between migraineurs }\end{array}$ \\
\hline & & Controls: 25 & & & & \\
\hline Thomsen, 1996 [26] & $\mathrm{CC}$ & MwoA: 12 & 100 & Use of any daily drugs & ICHD-I & No differences in FMD \\
\hline & & Controls: 12 & & & & $\begin{array}{l}\text { between migraineurs } \\
\text { and controls }\end{array}$ \\
\hline Vanmolkot, 2007 [27] & $\mathrm{CC}$ & Migraine: 50 & 78 & Age >50, CVD, HYP, obesity, DM, & Validated & Decreased FMD in \\
\hline & & Controls: 50 & & $\begin{array}{l}\text { dyslipidemia, pregnancy or lactation, } \\
\text { use of vasoactive drugs (except OC) }\end{array}$ & questionnaire & migraineurs \\
\hline Vernieri, 2010 [28] & $\mathrm{CC}$ & Migraine:21 & & None & ICHD-II & FMD increased from \\
\hline & & (MwA: 11; MwoA: 10) & & & & $\begin{array}{l}\text { controls to MwoA to } \\
\text { MwA patients }\end{array}$ \\
\hline & & Controls: 13 & & & & \\
\hline Yetkin, 2006 [29] & $\mathrm{CC}$ & Migraine: 45 & 80 & CAD, HYP, obesity, DM, infectious & ICHD-I & Decreased FMD in \\
\hline & & Controls: 45 & & disease, ovarium pathology & & migraineurs \\
\hline Yetkin, 2007 [30] & $\mathrm{CC}$ & Migraine: 24 & 89 & HYP, CAD, DM, infectious disease & ICHD-I & Decreased FMD in \\
\hline & & Controls: 26 & & & & \\
\hline
\end{tabular}

CC case-control; MwA migraine with aura; MwoA migraine without aura; CVD cardiovascular disease; HYP arterial hypertension; DM diabetes mellitus; CS cigarette smoking; RF risk factors; FANS non steroid anti-inflammatory drugs; OC oral contraceptives; CAD coronary artery disease; ICHD International classification headache disorders; FMD flow-mediated dilation.

\section{Arterial function in migraineurs}

Compared with studies on endothelial function, reports on arterial function measured with PWV, AIx, and local arterial distensibility are more consistent and suggest that functional properties of large arteries are altered in migraineurs [27,42-46] (Table 5).

Four studies addressed PWV in migraineurs (Table 5) [27,42-44]. Ikeda et al. evaluated peripheral PWV [42] while the other authors assessed central PWV [27,43,44]. Three studies on PWV $[27,42,43]$ found higher values of this parameter in migraineurs with respect to nonmigraineurs. However, in one of the studies PWV did not correlate with the presence of migraine after adjustment for age and mean arterial pressure [27]. The inclusion in the study of patients with a short history of migraine and with less use of vasoconstrictive agents may explain the difference [27]. Schillaci et al., also addressed PWV according to migraine type and reported that subjects with migraine either with or without aura had increased PWV with respect to controls while migraine with aura subjects had higher aortic PWV than those without aura [43]. A more recent populationbased study, involving a larger number of migraineurs, has challenged the suggestion of possible impairment 
Table 3 Studies on endothelial function by arterial tonometry or vasodilation in response to pharmacological stimuli in migraineurs

\begin{tabular}{|c|c|c|c|c|c|c|}
\hline $\begin{array}{l}\text { Study (First } \\
\text { author, year) }\end{array}$ & $\begin{array}{l}\text { Study } \\
\text { design }\end{array}$ & $\begin{array}{c}\text { Patients } \\
\text { included (n) }\end{array}$ & $\begin{array}{c}\% \\
\text { women }\end{array}$ & $\begin{array}{l}\text { Exclusion } \\
\text { criteria }\end{array}$ & $\begin{array}{l}\text { Migraine } \\
\text { diagnosis }\end{array}$ & Results \\
\hline \multicolumn{7}{|l|}{ Arterial tonometry } \\
\hline \multirow[t]{2}{*}{ Jiménez-Caballero, 2013 [31] } & \multirow[t]{2}{*}{$\mathrm{CC}$} & CM: 21 & \multirow[t]{2}{*}{71} & \multirow[b]{2}{*}{$\begin{array}{l}\text { Age } \geq 50 \text {, CVD, inflammatory } \\
\text { disease, obesity, HYP, DM, } \\
\text { dyslipidemia, CS, active } \\
\text { cancer, ovarium pathology, } \\
\text { pregnancy or lactation, } \\
\text { regular use of vasoactive } \\
\text { drugs }\end{array}$} & \multirow[t]{2}{*}{ ICHD-|| } & \multirow[t]{2}{*}{ Smaller RHI in migraineurs } \\
\hline & & Controls: 21 & & & & \\
\hline \multirow[t]{2}{*}{ Liman, 2012 [32] } & \multirow[t]{2}{*}{ CC } & MwA: 29 & \multirow[t]{2}{*}{100} & \multirow{2}{*}{$\begin{array}{l}\text { CVD, obesity, HYP, DM, } \\
\text { pregnancy, use of drugs } \\
\text { (statins, anticoagulants or } \\
\text { antiplatelet and intake of } \\
\text { triptans within the } \\
\text { previous } 24 \mathrm{~h} \text { ) }\end{array}$} & \multirow[t]{2}{*}{ ICHD-II } & \multirow{2}{*}{$\begin{array}{l}\text { No differences in PAT ratio } \\
\text { between migraineurs } \\
\text { and controls }\end{array}$} \\
\hline & & Controls: 30 & & & & \\
\hline \multicolumn{7}{|c|}{ Vasodilation in response to pharmacological stimuli } \\
\hline \multirow[t]{2}{*}{ De Hoon, 2006 [20] } & \multirow[t]{2}{*}{$\mathrm{CC}$} & Migraine: 10 & \multirow[t]{2}{*}{60} & \multirow{2}{*}{$\begin{array}{l}\text { CVD, HYP, DM, } \\
\text { dyslipidemia, CS }\end{array}$} & \multirow[t]{2}{*}{ ICHD-I } & \multirow{2}{*}{$\begin{array}{l}\text { No differences between } \\
\text { migraineurs and controls in } \\
\text { vasodilation response to } \\
\text { serotonin, sodium } \\
\text { nitroprusside, and CGRP }\end{array}$} \\
\hline & & Controls: 10 & & & & \\
\hline \multirow[t]{2}{*}{ Edvinsson, 2008 [33] } & \multirow[t]{2}{*}{$\mathrm{CC}$} & MwoA: 9 & \multirow[t]{2}{*}{78} & \multirow[t]{2}{*}{ None } & \multirow[t]{2}{*}{ ICHD-I } & \multirow{2}{*}{$\begin{array}{l}\text { No differences between } \\
\text { migraineurs and controls in } \\
\text { vasodilation response after } \\
\text { local heating and iontophoretic } \\
\text { administration of acetylcholine, } \\
\text { sodium nitroprusside, and CGRP }\end{array}$} \\
\hline & & Controls: 9 & & & & \\
\hline \multirow[t]{2}{*}{ Napoli, 2009 [34] } & \multirow[t]{2}{*}{$\mathrm{CC}$} & MwoA: 12 & \multirow[t]{2}{*}{58} & \multirow{2}{*}{$\begin{array}{l}\text { HYP, DM, } \\
\text { hypercholesterolemia, } \\
\text { CVD, CS }\end{array}$} & \multirow[t]{2}{*}{ ICHD-I } & \multirow{2}{*}{$\begin{array}{l}\text { Reduced response to } \\
\text { endothelium-dependent } \\
\text { vasodilation and production } \\
\text { of cGMP in migraineurs; no } \\
\text { difference in production of NO }\end{array}$} \\
\hline & & Controls: 12 & & & & \\
\hline \multirow[t]{2}{*}{ Vanmolkot, 2010 [35] } & \multirow[t]{2}{*}{$\mathrm{CC}$} & Migraine:16 & \multirow[t]{2}{*}{75} & \multirow{2}{*}{$\begin{array}{l}\text { Age }>50, C V D, H Y P \text {, } \\
\text { obesity, DM, CS, } \\
\text { dyslipidemia, pregnancy } \\
\text { or lactation, use of } \\
\text { vasoactive drugs } \\
\text { (except OC) }\end{array}$} & \multirow[t]{2}{*}{ ICHD-II } & No differences between \\
\hline & & Controls: 16 & & & & $\begin{array}{l}\text { migraineurs and controls to } \\
\text { sodium nitroprusside, substance } \\
\mathrm{P} \text {, and } \mathrm{N}^{\mathrm{G}} \text {-monomethyl-L-arginine }\end{array}$ \\
\hline Yetkin, 2007 [30] & $\mathrm{CC}$ & Migraine: 24 & 89 & $\begin{array}{l}\text { HYP, CAD, DM, } \\
\text { infectious disease }\end{array}$ & ICHD-I & $\begin{array}{l}\text { Higher nitrate-mediated dilation } \\
\text { in migraineurs }\end{array}$ \\
\hline & & Controls: 26 & & & & \\
\hline
\end{tabular}

CC case-control; CM chronic migraine; MwA migraine with aura; MwoA migraine without aura; CVD cardiovascular disease; HYP arterial hypertension; DM,diabtes mellitus; CS cigarette smoking; OC oral contraceptive; ICHD International classification headache disorders; $R H I$ reactive hyperhemia index; $P A T$ peripheral arterial tonometry; CGRP Calcitonin Gene Related Peptide; CGMP cyclic guanosine monophosphate; NO nitric oxide.

of arterial function in migraineurs [44]. In fact, Stam et al. reported no differences in PWV among subjects with migraine with aura, migraine without aura, and controls [44]. In this latter study subjects with known cardiovascular risk factors were included and this may explain the differences in the results [44].

Higher values of AIx were found in migraineurs by five studies [27,31,32,43,45], which variously measured AIx in the radial artery [45], in the aorta $[27,43]$ or by finger tonometry [31,32]. One of those studies involved only women with migraine with aura [32] and one involved only subjects with chronic migraine [31]. Schillaci et al. reported increased AI in migraine with and without aura with respect to controls and no differences between the two groups of migraineurs [43]. All the studies about AIx had a case-control design, except for a populationbased one [45] which involved cases and controls older than those of the other studies.

Two studies assessed static arterial parameters $[27,46]$. De Hoon et al. found that migraineurs had larger temporal artery diameter compared with control subjects but a decreased distensibility and buffering capacity of the brachial artery in the absence of significant alterations in the common carotid and femoral arteries 
Table 4 Studies on endothelial function by endothelial progenitor cells in migraineurs

\begin{tabular}{|c|c|c|c|c|c|c|}
\hline $\begin{array}{l}\text { Study (First } \\
\text { author, year) }\end{array}$ & $\begin{array}{l}\text { Study } \\
\text { design }\end{array}$ & $\begin{array}{c}\text { Patients } \\
\text { included (n) }\end{array}$ & $\begin{array}{c}\% \\
\text { women } \\
\end{array}$ & $\begin{array}{l}\text { Exclusion } \\
\text { criteria }\end{array}$ & $\begin{array}{l}\text { Migraine } \\
\text { diagnosis }\end{array}$ & Results \\
\hline \multirow[t]{3}{*}{ Lee, 2008 [36] } & \multirow[t]{3}{*}{$\mathrm{CC}$} & Migraine: 92 & \multirow[t]{3}{*}{70} & \multirow[t]{3}{*}{ CVD, diabetic retinopathy } & \multirow[t]{3}{*}{ |CHD-|| } & \multirow{3}{*}{$\begin{array}{l}\text { Decreased number and migratory } \\
\text { capacity and higher senescence } \\
\text { levels of endothelial progenitor } \\
\text { cells in migraineurs versus } \\
\text { controls }\end{array}$} \\
\hline & & (MwoA: 67; MwA: 25) & & & & \\
\hline & & Controls: 37 & & & & \\
\hline \multirow[t]{3}{*}{ Oterino, 2013 [37] } & \multirow[t]{3}{*}{$\mathrm{CC}$} & CM: 51 & \multirow[t]{3}{*}{73} & \multirow{3}{*}{$\begin{array}{l}\text { CVD, inflammatory disease, } \\
\text { cancer or treatment with } \\
\text { antimitogen agents, pregnancy } \\
\text { in the last year }\end{array}$} & \multirow[t]{3}{*}{ ICHD-I } & \multirow{3}{*}{$\begin{array}{l}\text { Higher number of activated } \\
\text { endothelial progenitor cells } \\
\text { in migraineurs }\end{array}$} \\
\hline & & EM: 48 & & & & \\
\hline & & Controls: 35 & & & & \\
\hline \multirow[t]{3}{*}{ Rodriguez-Osorio, 2012 [23] } & \multirow[t]{3}{*}{$\mathrm{CC}$} & Migraine : 47 & \multirow[t]{3}{*}{98} & \multirow{3}{*}{$\begin{array}{l}\text { CAD, inflammatory disease, } \\
\text { obesity, HYP, DM, dyslipidemia, } \\
\text { CS, infectious disease, severe } \\
\text { systemic disease; ovarium } \\
\text { pathology, pregnancy or } \\
\text { lactation, use of vasoactive } \\
\text { drugs }\end{array}$} & \multirow[t]{3}{*}{ ICHD-\| } & \multirow{3}{*}{$\begin{array}{l}\text { Lower endothelial progenitor cell } \\
\text { counts in migraineurs }\end{array}$} \\
\hline & & (MwA:14; MwoA: 33) & & & & \\
\hline & & Controls: 23 & & & & \\
\hline
\end{tabular}

CC case-control; $C M$ chronic migraine; EM episodic migraine; MwA migraine with aura; MwoA migraine without aura; CVD cardiovascular disease; $C A D$ coronary artery disease; HYP arterial hypertension; DM diabetes mellitus; CS cigarette smoking; ICHD International classification headache disorders.

[46]. Vanmolkot et al. found that migraineurs had a decreased diameter and compliance of superficial muscular arteries [27].

\section{Discussion}

The results of the systematic review suggest the presence of a peripheral vascular dysfunction in migraineurs. However, while several studies support an alteration of arterial function among subjects with migraine, findings on the endothelial function are less clear.

Endothelial function in migraineurs has sometimes been reported as impaired and sometimes as altered, while some studies found no difference compared with endothelial function in controls. Differences among available studies may be explained by various inclusion/ exclusion criteria and the generally small number of participants. Migraine, and particularly migraine with aura, has been associated with an elevated cardiovascular profile. The exclusion of subjects with cardiovascular risk factors from some of the studies may at least partly explain the described differences. Duration of migraine, severity of attacks and the active or inactive state of the disease may also have played a role in the betweenstudy differences in results. To clarify the status of endothelial function in migraineurs further, studies are required that need to involve large number of subjects of properly selected individuals, applying rigorous inclusion and exclusion criteria, and including subjects with a wide range of migraine conditions in terms of frequency, duration, and severity of the attacks. In addition, further studies should also adopt a standardized and reliable methodology to address endothelial function.
Regarding arterial function, most of the available evidence supports greater stiffness or impaired compliance of the arterial system in migraineurs. The mechanisms underlying the association between migraine and altered arterial function are likely to be complex and may involve both structural and functional changes in the arterial wall. Since all the studies had a cross-sectional design, a cause-effect relationship between migraine and increased arterial stiffness cannot be established. However, migraine usually starts in early adulthood, at an age in which arterial wall pathologies are rare. In the general population alteration in arterial function has been associated with the presence of vascular risk factors and is considered a marker of vascular disease associated with risk of future vascular events $[47,48]$. Since most studies addressing arterial function in migraineurs excluded subjects with comorbid vascular risk factors, other mechanisms can be hypothesized. The possible hypotheses include alterations in vessel wall structure in migraineurs as supported by the presence of impaired serum elastase activity [49], higher sympathetic tone $[50,51]$, use of drugs such as triptans and ergot derivatives, or it may represent a primary alteration linked to the presence of migraine itself [52]. At the moment it is unknown whether the duration of migraine and the frequency and severity of the attacks has an impact on arterial stiffness. Moreover, gender differences may also play a role in determining arterial stiffness in migraineurs with females being more susceptible to changes [43]. In addition, possible clinical implications of arterial dysfunction in migraineurs have to be clarified. In the general population, arterial dysfunction has been linked to an increased risk of vascular disease through an atherothrombotic mechanism $[47,48]$. However, in migraineurs 
Table 5 Studies on arterial function in migraineurs

\begin{tabular}{|c|c|c|c|c|c|c|c|}
\hline $\begin{array}{l}\text { Study (First } \\
\text { author, year) }\end{array}$ & $\begin{array}{l}\text { Study } \\
\text { design }\end{array}$ & $\begin{array}{c}\text { Patients } \\
\text { included (n) }\end{array}$ & $\begin{array}{c}\% \\
\text { women }\end{array}$ & $\begin{array}{l}\text { Exclusion } \\
\text { criteria }\end{array}$ & $\begin{array}{l}\text { Migraine } \\
\text { diagnosis }\end{array}$ & $\begin{array}{l}\text { Parameters } \\
\text { assessed }\end{array}$ & Results \\
\hline \multirow{3}{*}{$\begin{array}{l}\text { De Hoon, } \\
2003 \text { [46] }\end{array}$} & \multirow[t]{3}{*}{$\mathrm{CC}$} & MwA: 11 & \multirow[t]{3}{*}{76} & \multirow{3}{*}{$\begin{array}{l}\text { CVD, inflammatory } \\
\text { disease, HYP, DM, } \\
\text { dyslipidemia }\end{array}$} & \multirow[t]{3}{*}{ ICHD-I } & \multirow{3}{*}{$\begin{array}{l}\text { Diameter and compliance } \\
\text { parameters of brachial, } \\
\text { carotid, femoral, and } \\
\text { temporal arteries }\end{array}$} & \multirow{3}{*}{$\begin{array}{l}\text { Smaller diameter and } \\
\text { distension of brachial arteny } \\
\text { and larger right temporal } \\
\text { artery diameter in } \\
\text { migraineurs; no differences } \\
\text { in carotid and femoral } \\
\text { arteries }\end{array}$} \\
\hline & & MwoA: 39 & & & & & \\
\hline & & Controls: 50 & & & & & \\
\hline \multirow[t]{3}{*}{ Ikeda, 2011 [42] } & \multirow[t]{3}{*}{$\mathrm{CC}$} & MwA:22 & \multirow[t]{3}{*}{73} & \multirow[t]{3}{*}{ CVD, vascular RF } & \multirow[t]{3}{*}{ ICHD-\|I } & \multirow[t]{3}{*}{ Brachial PWV } & \multirow[t]{3}{*}{ Higher PW in migraineurs } \\
\hline & & MwoA:89 & & & & & \\
\hline & & Controls:110 & & & & & \\
\hline \multirow{2}{*}{$\begin{array}{l}\text { Jiménez-Caballero, } \\
2013 \text { [31] }\end{array}$} & \multirow[t]{2}{*}{$\mathrm{CC}$} & CM: 21 & \multirow[t]{2}{*}{71} & \multirow{2}{*}{$\begin{array}{l}\text { Age } \geq 50 \text {, CVD, } \\
\text { inflammatory disease, } \\
\text { obesity, HYP, DM, } \\
\text { dyslipidemia }\end{array}$} & \multirow[t]{2}{*}{ ICHD-II } & \multirow[t]{2}{*}{ Radial Alx } & \multirow[t]{2}{*}{ Higher Alx in migraineurs } \\
\hline & & Controls: 21 & & & & & \\
\hline \multirow[t]{2}{*}{ Liman, 2012 [32] } & \multirow[t]{2}{*}{$\mathrm{CC}$} & MwA: 29 & \multirow[t]{2}{*}{100} & \multirow{2}{*}{$\begin{array}{l}\text { CVD, obesity, } \\
\text { arterial HYP, DM }\end{array}$} & \multirow[t]{2}{*}{ ICHD-II } & \multirow[t]{2}{*}{ Peripheral Alx } & \multirow[t]{2}{*}{ Higher Aix in migraineur } \\
\hline & & Controls: 30 & & & & & \\
\hline \multirow[t]{4}{*}{ Nagai, 2007 [45] } & \multirow[t]{4}{*}{ PB } & Group A:134 & \multirow[t]{4}{*}{93} & \multirow[t]{4}{*}{ Stroke } & \multirow{4}{*}{$\begin{array}{l}\text { Validated } \\
\text { questionnaire }\end{array}$} & \multirow{4}{*}{ Radial Alx } & Higher Alx in migraineurs \\
\hline & & (5\% migraineurs) & & & & & \\
\hline & & Group B:138 & & & & & \\
\hline & & (17\% migraineurs) & & & & & \\
\hline Schillaci, 2010 [43] & $\mathrm{CC}$ & MwA:17 & 85 & CVD, inflammatory & ICHD-II & Aortic PWV and & Higher PWV and Alx in \\
\hline & & MwoA: 43 & & $\begin{array}{l}\text { disease, HYP, DM, } \\
\text { dyslipidemia }\end{array}$ & & & $\begin{array}{l}\text { migraineurs, especially } \\
\text { in MwA }\end{array}$ \\
\hline & & Controls:60 & & & & & \\
\hline Stam, 2013 [44] & PB & MwA: 123 & 75 & None & ICHD-II & Carotid and femoral & No differences between \\
\hline & & MwoA: 167 & & & & & mıgraıneurs and controls \\
\hline & & Controls: 542 & & & & & \\
\hline Vanmolkot, & $\mathrm{CC}$ & Migraine: 50 & 78 & None & ICHD-I & Diameter and compliance & Smaller brachial artery \\
\hline & & Controls: 50 & & & & $\begin{array}{l}\text { femoral arteries, aortic Alx } \\
\text { and aortic PWW }\end{array}$ & $\begin{array}{l}\text { and smaller femoral artery } \\
\text { diameter in migraineurs; } \\
\text { higher aortic Alx in } \\
\text { migraineurs; higher PWW } \\
\text { in migraineurs not } \\
\text { confirmed after adjustment } \\
\text { for age and mean arterial } \\
\text { pressure }\end{array}$ \\
\hline
\end{tabular}

CC case-control; $P B$ population-based; $C M$ chronic migraine; $M w A$, migraine with aura; $M w O A$, migraine without aura; $C V D$, cardiovascular disease; $H Y P$, arterial hypertension; $D M$, diabetes mellitus; $R F$, risk factors; ICHD, International classification headache disorders; $A I x$, augmentation index; $P W V$, pulse wave velocity.

the evidence of an atherothrombotic mechanism leading to vascular events is not supported and much evidence points against this possibility. [53,54] In fact, intima-media thickness (IMT), which is a surrogate marker of subclinical atherosclerosis has not been consistently linked to migraine status $[20,24,27,55,56]$. In addition, despite little information being available on the frequency of the different subtypes of ischemic stroke in migraineurs, the available studies do not support an increased atherosclerotic load $[57,58]$. Also the cardiac events observed in migraineurs did not seem to be attributable to atherothrombosis and alternative mechanisms have been hypothesized [59-61]. Future studies should also clarify whether the vascular dysfunction may represent a marker able to identify those migraineurs who are at higher risk of presenting vascular events and who might be the target of possible preventive strategies.

\section{Conclusion}

The study of systemic vascular function is a promising tool for non-invasively investigating the vascular health of subjects with migraine. At the moment, evidence is too scarce to support the clinical application of the techniques and further research studies are needed to better clarify all the pending issues. 


\section{Additional file}

\section{Additional file 1: Online references.}

\section{Competing interests}

The authors declare that they have no competing interests.

\section{Authors' contributions}

All authors of this manuscript (SS, PR, DG, RO, FP, AC, TK) have made substantial contributions to conception and design of the review, have been involved in drafting the manuscript and revising it critically for important intellectual content and have given final approval of the version to be published.

\section{Author details}

'Department of Neurology and Regional Headache Center, University of L'Aquila, Piazzale Salvatore Tommasi 1, L'Aquila 67100, Italy. ${ }^{2}$ Department of Life, Health, and Eviromental Sciences, University of L'Aquila, L'Aquila 67100, Italy. ${ }^{3}$ Inserm Research Center for Epidemiology and Biostatistics, Team Neuroepidemiology, Bordeaux F-33000, France. ${ }^{4}$ University of Bordeaux, Bordeaux F-33000, France.

\section{Received: 5 August 2013 Accepted: 20 September 2013}

\section{Published: 1 October 2013}

\section{References}

1. Connor RC (1962) Complicated migraine. A study of permanent neurological and visual defects caused by migraine. Lancet 2:1072-1075

2. Carolei A, Marini C, Di Napoli M, Di Gianfilippo G, Santalucia P, Baldassarre M, De Matteis G, di Orio F (1997) High stroke incidence in the prospective community-based L'Aquila registry (1994-1998). First year's results. Stroke 28:2500-2506

3. Tzourio C, Iglesias S, Hubert JB, Visy JM, Alpérovitch A, Tehindrazanarivelo A, Biousse V, Woimant F, Bousser MG (1993) Migraine and risk of ischaemic stroke: a case-control study. BMJ 307:289-292

4. Kurth T, Diener HC (2012) Migraine and stroke: perspectives for stroke physicians. Stroke 43:3421-3426

5. Kurth T, Chabriat H, Bousser MG (2012) Migraine and stroke: a complex association with clinical implications. Lancet Neurol 11:92-100

6. Sacco S, Ricci S, Carolei A (2012) Migraine and vascular diseases: a review of the evidence and potential implications for management. Cephalalgia 32:785-795

7. Sacco S, Ornello R, Ripa P, Pistoia F, Carolei A (2013) Migraine and hemorrhagic stroke: a meta-analysis. Stroke, in press

8. Bigal ME, Kurth T, Hu H (2009) Migraine and cardiovascular disease: possible mechanisms of interaction. Neurology 72:1864-1871

9. Sacco S, Olivieri L, Bastianello S, Carolei A (2006) Comorbid neuropathologies in migraine. J Headache Pain 7:222-230

10. Sacco S, Cerone D, Carolei A (2008) Comorbid neuropathologies in migraine: an update on cerebrovascular and cardiovascular aspects. J Headache Pain 9:237-248

11. Brunner H, Cockcroft JR, Deanfield J, Donald A, Ferrannini E, Halcox J, Kiowski W, Lüscher TF, Mancia G, Natali A, Oliver JJ, Pessina AC, Rizzoni D, Rossi GP, Salvetti A, Spieker LE, Taddei S, Webb DJ, Working Group on Endothelins and Endothelial Factors of the European Society of Hypertension (2005) Endothelial function and dysfunction. Part II: Association with cardiovascular risk factors and diseases. A statement by the Working Group on Endothelins and Endothelial Factors of the European Society of Hypertension. J Hypertens 23:233-246

12. Davignon J, Ganz P (2004) Role of endothelial dysfunction in atherosclerosis. Circulation 109:11127-3

13. Tomiyama H, Yamashina A (2010) Non-invasive vascular function tests: their pathophysiological background and clinical application. Circ J 74:24-33

14. Widlansky ME, Gokce N, Keaney JF Jr, Vita JA (2003) The Clinical Implications of Endothelial Dysfunction. J Am Coll Cardiol 42:1149-1160

15. Ross R (1999) Atherosclerosis-an inflammatory disease. N Engl J Med 340:115-126

16. Flammer AJ, Anderson T, Celermajer DS, Creager MA, Deanfield J, Ganz P, Hamburg NM, Lüscher TF, Shechter M, Taddei S, Vita JA, Lerman A (2012)
The assessment of endothelial function: from research into clinical practice. Circulation 126:753-767

17. Al-Qaisi M, Kharbanda RK, Mittal TK, Donald AE (2008) Measurement of endothelial function and its clinical utility for cardiovascular risk. Vasc Health Risk Manag 4:647-652

18. Corretti MC, Anderson TJ, Benjamin EJ, Celermajer D, Charbonneau F, Creager MA, Deanfield J, Drexler H, Gerhard-Herman M, Herrington D, Vallance P, Vita J, Vogel R, International Brachial Artery Reactivity Task Force (2002) Guidelines for the ultrasound assessment of endothelial-dependent flow-mediated vasodilation of the brachial artery: a report of the International Brachial Artery Reactivity Task Force. J Am Coll Cardiol 39:257-265

19. Joannides R, Haefeli WE, Linder L, Richard V, Bakkali EH, Thuillez C, Lüscher TF (1995) Nitric oxide is responsible for flow-dependent dilatation of human peripheral conduit arteries in vivo. Circulation 91:1314-1319

20. De Hoon JN, Smits P, Troost J, Struijker-Boudier HA, Van Bortel LM (2006) Forearm vascular response to nitric oxide and calcitonin gene-related peptide: comparison between migraine patients and control subjects. Cephalalgia 26:56-63

21. Hamed SA, Hamed EA, Ezz Eldin AM, Mahmoud NM (2010) Vascular Risk Factors, Endothelial Function, and Carotid Thickness in Patients with Migraine: Relationship to Atherosclerosis. J Stroke Cerebrovasc Dis 19:92-103

22. Perko D, Pretnar-Oblak J, Šabovič M, Zaletel M, Žvan B (2011) Associations between cerebral and systemic endothelial function in migraine patients: a post-hoc study. BMC Neurol 11:146

23. Rodríguez-Osorio X, Sobrino T, Brea D, Martínez F, Castillo J, Leira R (2012) Endothelial progenitor cells: a new key for endothelial dysfunction in migraine. Neurology 79:474-479

24. Rossato A, Veronese F, Maggioni F, Vedovetto V, Zancan A, Biasiolo M, Bilora $F$ (2011) Autonomic dysfunction and endothelial changes in migraine sufferers. Panminerva Med 53:13-18

25. Silva FA, Rueda-Clausen CF, Silva SY, Zarruk JG, Guzmán JC, Morillo CA, Vesga B, Pradilla G, Flórez M, López-Jaramillo P (2007) Endothelial function in patients with migraine during the interictal period. Headache 47:45-51

26. Thomsen LL, Daugaurd D, Iversen H (1996) Normal radial artery dilatation during reactive hyperaemia in migraine without aura. Endothelium 4:199-206

27. Vanmolkot FH, Van Bortel LM, de Hoon JN (2007) Altered arterial function in migraine of recent onset. Neurology 68:1563-1570

28. Vernieri F, Moro L, Altamura C, Palazzo P, Antonelli Incalzi R, Rossini PM, Pedone C (2010) Patients with migraine with aura have increased flow mediated dilation. BMC Neurol 10:18

29. Yetkin E, Ozisik H, Ozcan C, Aksoy Y, Turhan H (2006) Decreased endothelium-dependent vasodilatation in patients with migraine: a new aspect to vascular pathophysiology of migraine. Coron Artery Dis 17:29-33

30. Yetkin E, Ozisik H, Ozcan C, Aksoy Y, Turhan H (2007) Increased dilator response to nitrate and decreased flow-mediated dilatation in migraineurs. Headache 47:104-110

31. Jiménez Caballero PE, Muñoz Escudero F (2013) Peripheral endothelial function and arterial stiffness in patients with chronic migraine: a casecontrol study. J Headache Pain 14:8

32. Liman TG, Neeb L, Rosinski J, Wellwood I, Reuter U, Doehner W, Heuschmann PU, Endres M (2012) Peripheral endothelial function and arterial stiffness in women with migraine with aura: a case-control study. Cephalalgia 32:459-466

33. Edvinsson ML, Edvinsson L (2008) Comparison of CGRP and NO responses in the human peripheral microcirculation of migraine and control subjects. Cephalalgia 28:563-566

34. Napoli R, Guardasole V, Zarra E, Matarazzo M, D'Anna C, Saccà F, Affuso F, Cittadini A, Carrieri PB, Saccà L (2009) Vascular smooth muscle cell dysfunction in patients with migraine. Neurology 72:2111-2114

35. Vanmolkot FH, de Hoon JN (2010) Endothelial function in migraine: a crosssectional study. BMC Neurol 10:119

36. Lee ST, Chu K, Jung KH, Kim DH, Kim EH, Choe VN, Kim JH, Im WS, Kang L, Park JE, Park HJ, Park HK, Song EC, Lee SK, Kim M, Roh JK (2008) Decreased number and function of endothelial progenitor cells in patients with migraine. Neurology 70:1510-1517

37. Oterino A, Toriello M, Palacio E, Quintanilla VG, Ruiz-Lavilla N, Montes S, Vega MS, Martinez-Nieto R, Castillo J, Pascual J (2013) Analysis of endothelial precursor cells in chronic migraine: a case-control study. Cephalalgia 33:236-244

38. George J, Shmilovich H, Deutsch V, Miller H, Keren G, Roth A (2006) Comparative analysis of methods for assessment of circulating endothelial progenitor cells. Tissue Eng 12:331-335 
39. Fidan I, Yüksel S, Ymir T, Irkeç C, Aksakal FN (2006) The importance of cytokines, chemokines and nitric oxide in pathophysiology of migraine. J Neuroimmunol 171:184-188

40. Tietjen GE, Herial NA, White L, Utley C, Kosmyna JM, Khuder SA (2009) Migraine and biomarkers of endothelial activation in young women. Stroke 40:2977-2982

41. Javanmard SH, Sonbolestan SA, Heshmat-Ghahdarijani K, Saadatnia M, Sonbolestan SA (2011) Enalapril improves endothelial function in patients with migraine: A randomized, double-blind, placebo-controlled trial. J Res Med Sci 16:26-32

42. Ikeda K, Hirayama T, Iwamoto K, Takazawa T, Kawase Y, Yoshii Y, Kano O, Kawabe K, Tamura M, Iwasaki Y (2011) Pulse wave velocity study in middleaged migraineurs at low cardiovascular disease risk. Headache 51:1239-1244

43. Schillaci G, Sarchielli P, Corbelli I, Pucci G, Settimi L, Mannarino MR, Calabresi P, Mannarino E (2010) Aortic stiffness and pulse wave reflection in young subjects with migraine: A case-control study. Neurology 75:960-966

44. Stam AH, Weller CM, Janssens AC, Aulchenko YS, Oostra BA, Frants RR, van den Maagdenberg AM, Ferrari MD, van Duijn CM, Gisela MT (2013) Migraine is not associated with enhanced atherosclerosis. Cephalalgia 33:228-235

45. Nagai T, Tabara Y, Igase M, Nakura J, Miki T, Kohara K (2007) Migraine is associated with enhanced arterial stiffness. Hypertens Res 30:577-583

46. De Hoon JN, Willigers JM, Troost J, Struijker-Boudier HA, Van Bortel LM (2003) Cranial and peripheral interictal vascular changes in migraine patients. Cephalalgia 23:96-104

47. Grassi D, Desideri G, Ferri C (2011) Cardiovascular risk and endothelial dysfunction: the preferential route for atherosclerosis. Curr Pharm Biotechnol 12:1343-1353

48. Bonetti PO, Lerman LO, Lerman A (2003) Endothelial dysfunction: a marker of atherosclerotic risk. Arterioscler Thromb Vasc Biol 23:168-175

49. Tzourio C, Kittner SJ, Bousser MG, Alpérovitch A (2000) Migraine and stroke in young women. Cephalalgia 20:190-199

50. Cortelli P, Pierangeli G, Parchi P, Contin M, Baruzzi A, Lugaresi E (1991) Autonomic nervous system function in migraine without aura. Headache 31:457-462

51. Martín R, Ribera C, Moltó JM, Ruiz C, Galiano L, Matías-Guiu J (1992) Cardiovascular reflexes in patients with vascular headache. Cephalalgia 12:360-364

52. Sacco S, Ripa P, Carolei A (2011) Migraine attributed to genetic disorder: proposal of a new category. Cephalalgia 31:760-762

53. Ikeda K, Nakamura Y, Iwamoto K, Kawabe K, Iwasaki Y (2010) Ankle-brachial index in migraineurs. Headache 50:1215

54. Jurno ME, Chevtchouk L, Nunes AA, de Rezende DF, Jevoux Cda C, de Souza JA, Moreira Filho PF (2010) Ankle-brachial index, a screening for peripheral obstructive arterial disease, and migraine - a controlled study. Headache 50:626-630

55. Schwaiger J, Kiechl S, Stockner H, Knoflach M, Werner P, Rungger G, Gasperi A, Willeit J (2008) Burden of atherosclerosis and risk of venous thromboembolism in patients with migraine. Neurology 71:937-943

56. Tzourio C, Gagniere B, El Amrani M, Alperovitch A, Bousser MG (2003) Relationship between migraine, blood pressure and carotid thickness. A population-based study in the elderly. Cephalalgia 23:914-920

57. MacClellan LR, Giles W, Cole J, Wozniak M, Stern B, Mitchell BD, Kittner SJ (2007) Probable migraine with visual aura and risk of ischemic stroke: the stroke prevention in young women study. Stroke 38:2438-2445

58. Rist PM, Buring JE, Kase CS, Schürks M, Kurth T (2010) Migraine and functional outcome from ischemic cerebral events in women. Circulation 122:2551-2557

59. Ahmed B, Bairey Merz CN, McClure C, Johnson BD, Reis SE, Bittner V, Pepine CJ, Sharaf BL, Sopko G, Kelsey SF, Shaw L, WISE Study Group (2006) Migraines, angiographic coronary artery disease and cardiovascular outcomes in women. Am J Med 119:670-675

60. Kurth T, Gaziano JM, Cook NR, Bubes V, Logroscino G, Diener HC, Buring JE (2007) Migraine and risk of cardiovascular disease in men. Arch Intern Med 167:795-801

61. Rose KM, Carson AP, Sanford CP, Stang PE, Brown CA, Folsom AR, Szklo M (2004) Migraine and other headaches: associations with Rose angina and coronary heart disease. Neurology 63:2233-2239

\section{Submit your manuscript to a SpringerOpen ${ }^{\circ}$ journal and benefit from:}

- Convenient online submission

- Rigorous peer review

- Immediate publication on acceptance

- Open access: articles freely available online

- High visibility within the field

- Retaining the copyright to your article

Submit your next manuscript at $\gg$ springeropen.com 